Available online on 15.08.2021 at http://jddtonline.info
Open Access to Pharmaceutical and Medical Research
$\begin{gathered}\text { Copyright } \odot \text { (2021 The Author(s): This is an open-access article distributed under the terms of the CC BY-NC } 4.0 \\ \text { which permits unrestricted use, distribution, and reproduction in any medium for non-commercial use provided } \\ \text { the original author and source are credited }\end{gathered}$

Open Access Full Text Article the original author and source are credited

Review Article

\title{
Evidence-Based Therapeutic Benefits of Cupping Therapy (Hijāma): A Comprehensive Review
}

\author{
Hina V Kouser 1, (D) Mohd Nayab2*, Ayesha Tehseen³, Shaista Mahfooz ${ }^{4}$, Baig Ruqaiyya5, Mohd Anwar6 \\ ${ }_{1,3}$ PG Scholar, Dept. of Ilaj bit Tadbeer, NIUM, Bengaluru, India \\ ${ }^{2}$ Assistant Professor, Dept. of Ilaj bit Tadbeer, NIUM, Bengaluru, India \\ ${ }^{4}$ PG Scholar, Dept. of Tahaffuzi wa Samaji Tib, NIUM, Bengaluru, India \\ ${ }^{5}$ PG Scholar, Dept. ofIlmul Saidla, NIUM, Bengaluru, India \\ ${ }^{6}$ Professor \& Chairman, Dept. of Ilaj bit Tadbeer, AKTC, AMU, Aligarh, India
}

Article Info:

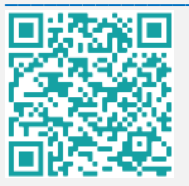

\section{Article History:}

Received 04 June 2021

Reviewed 09 July 2021

Accepted 17 July 2021

Published 15 August 2021

Cite this article as:

Kouser HV, Nayab M, Tehseen A, Mahfooz S,

Ruqaiyya B, Anwar M, Evidence-Based Therapeutic

Benefits of Cupping Therapy (Hijāma): A

Comprehensive Review, Journal of Drug Delivery

and Therapeutics. 2021; 11(4-S):258-262

DOI: http://dx.doi.org/10.22270/jddt.v11i4-S.4969

*Address for Correspondence:

Dr. Mohd Nayab, Assistant Professor, Department of

Ilaj Bit Tadbeer, National Institute of Unani

Medicine, Bangalore - 560091

ORCID ID: https://orcid.org/0000-0003-2077-9659

\section{Abstract}

Ilaj bi'l tadbeer (regimenal therapy) is one of the preferred treatment methods used in Unani system of medicine since ancient times. Hijāma is one of the effective modalities of treatment in Ilaj bi'l tadbeer. It is a unique therapeutic procedure in which cup like vessels are placed on the body surface by creating a vacuum to either let out blood from below the skin surface or just plain suction without bloodletting. The objective of this comprehensive review paper is to address the claims of Unāni physicians and clinical studies conducted on the efficacy of Hijāma. Various published clinical trials showed the efficacy of Hijāma in the management of a number of diseases. Though, the effect showed by some clinical trials was short term. Hence, it is suggested that rigorous, well-designed, controlled, randomized and long duration follow up clinical trials on large sample size are to be conducted by trained clinicians or researchers to establish the efficacy of Hijäma in the management of various diseases.

Keywords: Ilaj bi'l tadbeer, Hijāma, Therapeutic Benefits

\section{Introduction:}

Al Hijāma is an Arabic word which means application of cups and the literary meaning of Hijama is sucking1,2,3,4. It is a technique carried out by application of cup shaped glass vessels on the body surface, creating vacuum by heat or by special suction apparatus, in order to evacuate the morbid materials, to divert the material from the diseased part and to encourage the blood flow to the affected site ${ }^{1,5,6}$. Rāzi stated that cupping is a process of releasing the blood (toxic) from superficial small vessels located in muscles ${ }^{7}$. Hijāma can be defined as a minor surgical excretory procedure that creates superficial skin scarification to open skin barrier and creates a pressure gradient and a traction force across the skin and underlying capillaries to drain interstitial fluids and enhances blood clearance and waste excretion through skin ${ }^{8}$.

Classifications of Hijāma in Unani Medicine:

On the basis of scarification Hija $m a$ has been classified into two main types.
1. Hijāma bish-Shart (wet cupping /cupping with scarification)

2. Hijāma bilā-Sharț (dry cupping /cupping without scarification) $)^{9,10,11,12,13,14,15}$

Apart from these two types, Abul-qāsim-al-Zahrāwī has mentioned a third type of Hijäma in hisbook as follows ${ }^{16}$.

\section{Hijāma-i-Āabi (Hydro cupping)}

Hijāma bilā Shart is further divided into two types

a) Hijāma-Nāriyah/ba-ātish (cupping with fire)

b) Hijāma-Ghair-Nāriyah/be-ātish (cupping without fire) Further Hijäma is of two kinds on the basis of condition and situations

\section{Hijāma Iḍtirārī (Mandatory) \\ 2. Hijāma Ikhtiyārī (Optional) ${ }^{9,17}$}

On the basis of movement of cups, Hijāma bilā-Sharț is 
further subdivided into two types:

1. Hijama-i-Ghair Mutharrika (Stationary cupping)

2. Hijama-i-Mutaharrika (Gliding or moving cupping) ${ }^{18}$

\section{Mechanism of Action in Unani Medicine:}

Unani system of medicine which elaborates that cupping therapy works on the basis of two following fundamentals.

\section{Tanqiya-i-Mawād (Evacuation of morbid matter)}

\section{Imāla-i-Mawād (Diversion of morbid matter)}

In case of Hijāma bila Shart (Dry cupping) which works on the principle of Imāla-i-Mawād causes the diversion of morbid matter from one site to another.

In case of Hijāma bish Shart which works on the principle of Tanqiya-i-Mawād evacuates the morbid matter from the affected site 19,20,21. Jālinūs has mentioned that when the humours become thick in affected joint, Hijäma becomes very useful ${ }^{22}$. It opens the pores of the skin, enhances the blood circulation, nourish the affected area with fresh blood and improves the eliminative function which allows the Akhlāt-i-fāsida to be evacuated from the body. It helps to draw out and eliminate the imbalanced qualities i.e. Hār (heat), Bārid (cold), Rațab (moistness), Yābis (dryness) ${ }^{19}$.

\section{Mechanism of Action of in Modern Medicine:}

Exact mechanism of Hijāma bish Sharț is still unknown but many researchers tried to explain themechanism of action of Hijäma bish Shart through some theories like Pain gate theory, Prostaglandin theory, Endorphins and Encephalin production theory, Nitric oxide theory and Taibah theory etc. The short description of each of these theories is given as under ${ }^{23}$.

Pain gate theory: This theory states that there is a gate or channel to transfer pain signals from its actual site of origin to the brain. When suction cup is applied, it produces pain which interfere with the actual pain which can't be transmitted in the same gate or channel and in this way, elimination of pain occurs ${ }^{23}$.

Prostaglandin theory: Prostaglandins are produced as a result of inflammation in our body and these prostaglandins transmit pain signals to the brain. By doing Hijāma bish Shart, we take these products out from the body and this results in reduction of pain ${ }^{23,24}$.

Endorphins and encephalin production theory: These are natural components released in our body and these components are called 'endogenous please substances' which reduce the pain andenhance the mode ${ }^{23,24}$.

Nitric Oxide theory: Nitric oxide is very important substance released in the body as a result of any trauma, and it is released also during or after Hijāma bish Sharț. The functions of nitric oxide are:

1. Vasodilatation- this allows more blood flow to the area

2. Two-way vasodilatation effects

3. Muscle relaxation which cures spasms

4. Anti-thrombotic- protects the vessels from thrombosis

5. Anti-inflammatory and prevents stenosis of blood vessels ${ }^{23,24}$.

Taibah Theory: This theory is currently the most accurate scientific explanation of Hijāma's curative properties. It explains that Hijäma bish Sharț is a minor surgical excretory procedure and its effect is similar to the mechanism of excretory function via glomerular filtration of the kidney as well as abscess drainage, by which pathological substances are removed from the body 23 .

After reviewing many theories and discussion, it was concluded that wet cupping is dominated by control in (I) Neural, (II) Haematological, \& (III) Immune system functioning 25,26 .

In the neural system, effect occurs by regulation of neurotransmitters and hormones like serotonin, dopamine, endorphin, acetylcholine etc $24,25,27$.

In the haematological system, main effects occur by these two pathways:

1. Regulation of coagulation and anti-coagulation systems like decrease in the level of haematological element such as fibrinogen

2. Decrease in the hematocrit followed by increase in the blood flow and in the end organ oxygenation ${ }^{24,27}$.

In the immune system, main effects occur by these three pathways:

1. Irritation of the immune system by producing local simulated inflammation followed by activation of complementary system and increase level of immune products such as interferon and tumour necrotizing factors.

2. Organize of traffic of lymph and increase in the flow of lymph in the lymph vessels.

3. Effect on thymus 24,25 .

\section{Effect of Cupping therapy on Musculoskeletal system:}

Farhadi $\mathbf{K}$ et al. conducted a randomized trial to evaluate the efficacy of wet cupping therapy for nonspecific low back pain and concluded that wet cupping care was significantly more effective in reducing bodily pain than usual care at 3month follow-up ${ }^{26}$. Al Bedah A et el., through his study concluded that wet cupping is potentially effective in reducing pain and improving disability associated with persistent nonspecific low back pain at least for 2 weeks after the end of wet cupping period ${ }^{28}$. Kim JI et al. conducted a randomized, waiting-list controlled, open-label, parallelgroup pilot trial to evaluate the efficacy of wet cupping for persistent nonspecific low back pain and reported a significant improvement in pain in favor of wet cupping 29. Similarly, Mardani-Kivi $\mathbf{M}$ et al. conducted a randomized clinical trial to evaluate the efficacy of wet cupping on nonspecific low back pain and reported significant improvement in pain without any conventional treatment ${ }^{30}$. Lauche $\mathbf{R}$ et al. conducted a randomized controlled pilot study to evaluate the efficacy of a series of five dry cupping treatments on pain and mechanical thresholds in patients with chronic nonspecific neck pain and claimed that the patients of the treatment group had significant improvement in pain score after receiving cupping therapy than patients of the waiting-list control group 31 . Cramer $\mathbf{H}$ et al. studied to determine the efficacy of pulsating cupping for treating chronic neck pain. It was a randomized controlled clinical trial with two parallel groups. The authors concluded that Pneumatic pulsation cupping therapy appears to be a safe and effective method to relieve pain and to improve function and quality of life in patients with chronic neck pain ${ }^{32}$. Saha FJ et al. conducted a randomized controlled trial to evaluate the efficacy of cupping massage in patients with chronic neck pain and concluded that cupping massage appears to be effective in reducing pain and increasing 
function and quality of life in patients with chronic nonspecific neck pain ${ }^{33}$. Arslan $\mathbf{M}$ et al. conducted a pilot study to evaluate the effect of traditional wet cupping on shoulder and neck pain and the authors reported significant improvement in shoulder and neck pain ${ }^{34}$. Kim TH et al. concluded that two weeks of cupping therapy and an exerciseprogram is effective in reducing pain and improving neck function in video display terminal workers ${ }^{35}$. Lauche $\mathbf{R}$ et al. through his study concluded that significant increases were foundfor physical function and quality of life in patients with chronic nonspecific neck pain suggesting that cupping treatment might have sustainable effects for up to 2 years ${ }^{36}$ Similarly, Wen $\mathbf{M} \mathbf{X}$ et al. through his study concluded that wet cupping therapy provide a rapid therapeutic effect in nerve-root type cervical spondylosis, thus exhibiting significant analgesic effects ${ }^{37}$. Khan AA et al. conducted a randomized controlled clinical trial to evaluate the efficacy of dry cupping for osteoarthritis of knee. The authors reported a significant improvement in pain in favor of dry cupping 38 Abdullah KS et al. through his study concluded that cupping therapy has an ameliorative effect on Rheumatoid Arthritis by reducing the level of inflammatory markers such Creactive protein (CRP) and rheumatoid factor (RF) ${ }^{39}$. Bilal $\mathbf{M}$ et al. studied to determine the efficacy of wet cupping for treating sciatica pain. The authors reported a highly statistically significant effect of wet cupping in the treatment of sciatica pain and improvement in activities of daily livings ${ }^{40}$. Similarly, Shaikh $\mathbf{N}$ et al. through his study concluded that there is significant reduction in severity of symptoms and signs of sciatica after completion of the study ${ }^{41}$. Michalsen A et al. conducted a randomized controlled trial to evaluate the effects of traditional cupping therapy in patients with carpel tunnel syndrome. The authors concluded that asingle course of wet cupping of the shoulder triangle overlying the trapezius muscle appears to be effective in relieving symptoms and pain for at least 1 week $^{42}$. Similarly, Mohammadi S et al. through his study concluded that cupping therapy in a routine physical therapy program can reduce the severity of symptoms and improve the distal sensory disturbance of the median nerve ${ }^{43}$. Abuzar et al. concluded through a randomized controlled clinical trial that dry cupping is effective in the management of nonspecific low back pain ${ }^{44}$. A comparative study between the effects of dry cupping and soft and prolonged massage in the management of knee osteoarthritis was conducted by Islam MU et al. In this randomized controlled clinical trial, it was concluded that dry cupping is significantly effective in the management of knee osteoarthritis ${ }^{45}$.

\section{Effect of Cupping therapy on Reproductive system:}

Sultana A et al. studied to determine the efficacy of dry cupping for treating dysmenorrheal. The authors concluded that dry cupping is significant in reducing pain intensity in dysmenorrhea ${ }^{46}$. Dadmehr $\mathbf{M}$ et al. studied a case report to evaluate the efficacy of dry cupping therapy in the management of uterine fibroid and concluded that dry cupping therapy is effective and safe in decreasing fibroid related symptoms like dysmenorrhea and excess bleeding and also the size of the fibroid ${ }^{47}$. Sultana A et al. conducted a preliminary study to evaluate the efficacy of dry cupping on menorrhagia and concluded that dry cupping therapy is a useful treatment modality in decreasing the amount of menstrual blood flow in menorrhagia 48 . Abduljabbar $\mathbf{H}$ et al. conducted a pilot study to evaluate the efficacy of wet cupping for treating female infertility. The authors claimed that wet cupping is beneficial in infertile women for attaining pregnancy 49 . Azizkhani $\mathbf{M}$ et al. conducted a randomized controlled trial to evaluate the efficacy of dry cupping therapy in the treatment of idiopathic menorrhagia and concluded that dry cupping is an effective treatment in reducing the intensity of bleeding during the menstrual period compared to medroxyprogesterone acetate ${ }^{50}$. Khan AA et al. conducted a case report to evaluate the efficacy of wet cupping in the treatment of polycystic ovarian syndrome. The authors claimed that wet cupping regularizes menstrual cycle without fluctuating hormonal levels ${ }^{51}$. Mokaberinejad $\mathbf{R}$ et al. through his study concluded that Fennel seed infusion plus dry cupping therapy is effective and safe in reducing the days between two menstrual periods and manages oligomenorrhoea ${ }^{52}$.

\section{Effect of Cupping therapy on Nervous system:}

Ersoy $\mathbf{S}$ et al., conducted a randomized controlled trial to evaluate the efficacy of wet cupping therapy in migraine headache. The authors claimed that wet cupping therapy reduces pain and disability in migraine patients and that effectiveness increases as application continues ${ }^{53}$. Similarly, Seo J et al. through his study concluded that cupping has potential therapeutic effects on treating migraine ${ }^{54}$. Ali M et al. concluded that dry cupping along with Unani pharmacopeial formulation is effective in the management of hemiplegic stroke disabilities 5 .

\section{Effect of Cupping therapy on Circulatory system:}

Aleyeidi NA et al. conducted a randomized controlled trial to evaluate the efficacy of wet cupping in hypertensive patients. The authors concluded that wet cupping therapy is effective in reducing systolic blood pressure in hypertensive patients for up to 4 weeks ${ }^{56}$. Husain NR et al. conducted a single arm interventional study to evaluate the effect of wet cupping therapy on fasting blood sugar, renal function parameters, and endothelial function. The authors claimed that repeated wet cupping therapy improves the body's health which can lead to improvements in renal function and the prevention of metabolic diseases ${ }^{57}$. Nisari $\mathbf{M}$ et al. conducted a randomized controlled trial to evaluate the effect of wet cupping therapy on serum lipid concentrations of among healthy young men. The authors recommended that wet cupping therapy may be an effective therapy for reduction of LDL cholesterol concentrations and consequently may have a protective effect against atherosclerosis ${ }^{58}$. Fadli et al. conducted a randomized controlled trial to evaluate the effect of wet cupping against increased arterial baroreflex sensitivity in hypertensive patients. The authors concluded that wet cupping therapy effectively increases the sensitivity of arterial baroreflex with an indicator of decreased blood pressure in the elderly with hypertension up to a limit of 4 weeks after therapy ${ }^{59}$.

\section{Conclusion:}

Hijāma is one of the procedures of Ilaj bi'l tadbeer (Regimenal therapy) described in Unani system of medicine which includes evacuation of morbid matter from the body using cup shaped vessels. From the above discussion it can be concluded that Hijāma plays an important role in maintaining normal health, it is beneficial in both preventive and curative regimen. Hijäma is used effectively for the management of musculoskeletal, reproductive, circulatory and nervous disorders. Hence, we suggest rigorous, controlled, randomized and long-duration follow-up studies on large sample size, to be conducted by trained clinicians or researchers to establish the efficacy Hijäma in the management of various diseases. 


\section{References:}

1. Dar AK, Lone AH, Therapeutic application of Al-Hijamah (cupping therapy) in osteoarthritis of the knee, International Journal of Research and Development in Pharmacy \& Life Science, 2015; 4(3):1540-1544.

2. Sultana A, Rahman K, Hijamat (cupping therapy) and gynecological diseases-A Review, Journal of International Society for the History of Islamic Medicine (JISHIM), 2012; 1011(19-20-21-22):127-35.

3. Mohd Nayab, Mohd Anwar, Tanzeel Ahamd, Effect of Hijamatbila-Shurt in the Management of Waja-ul-Mafasil - A Clinical Study, Hippocratic Journal of Unani Medicine, Central Council for Research in Unani Medicine, New Delhi: 2009; 4(3):1-7.

4. Mohd Nayab, Mohd Arshad Ansari, Mohd Anwar, Ahmad Yasin, Effect of Hijamat-Bila-Shurt in the Management of Waja-uzZohar - A Clinical Study, Hippocratic Journal of Unani Medicine, Central Council for Research in Unani Medicine, New Delhi: 2011; 6(1):79-86.

5. Anjum N, Jamil S, Hannan A, Akhtar J, Ahmad B, Clinical Efficacy of Hijamat (Cupping) in Waja-ul-Mafasil. Indian Journal of Traditional Knowledge, 2005; 4(4):412-415.

6. Tagil SM, Celik HT, Ciftci S, Kazanci FH, Arslan M, Erdamar N et al., Wet- cupping removes oxidants and decreases oxidative stress, Complementary Therapies in Medicine, 2014; 22(6):1032-6. doi: 10.1016/j.ctim.2014.10.008.

7. Razi Z, Kitab Al Mansoori (Translated by the CCRUM), New Delhi: Central Council for Research in Unani Medicine, Ministry of Health and Family Welfare, Govt.ofIndia; 1991.

8. El Sayed SM, Mahmoud HS, Nabo MM, Medical and Scientific Bases of Wet Cupping Therapy: In Light of Modern Medicine and Prophetic Medicine, Alternative and Integrative Medicine, 2013; 2(5):1-6. doi: 10.4172/2327- 5162.1000122.

9. Masihi IQ, Kitab-al-Umda Fi-al-Jarahat (Translated by the CCRUM), Vol 1. New Delhi: Central Council for Research in Unani Medicine, Ministry of Health and FamilyWelfare, Govt. ofIndia; 1986.

10. Baghdadi IH. Kitab Al Mukhtarat Fit Tib (Translated by the CCRUM), Vol 1. New Delhi: Central Council for Research in Unani Medicine, Ministry of Healthand Family Welfare. Govt. of India; 2007.

11. Qarshi A, Mujaz-al-Qanun (urdu translated by Kauser chandpuri). $3^{\text {rd }}$ ed. New Delhi: NCPUL;1988.

12. Mohd. Nayab, Mehmooda Beghum, Mohd Anwar, Cupping Therapy - A Benevolent Boon of Unani System of Medicine, Unani Research, 2011; 1 (1):1-4.

13. Mohd Nayab, Mohd Anwar, Sherwani A.M.K, History of Hijamat, Journal of the International Society for the History of Islamic Medicine (JISHIM), 2012; 10-11(19-20-21-22): 175-179.

14. Qurshi HM, Jamiul Hikmat, New Delhi: Idara Kitab us Shifa; 2011.

15. Mohd Nayab, Abdul Nasir Ansari, Fatima Khan, A Panoramic view of most commonly used Regimenal Modalities (Tadabeer) for joint pain in Unani System of Medicine: A Critical Review, Journal of Drug Delivery and Therapeutics, 2021; 11(2):228231. DOI: http://dx.doi.org/10.22270/jddt.v11i2.4561.

16. Zahrawi AQ, Jarahiyat Zahrawi (Urdu translated by Nisar Ahmad HM). New Delhi: Central Council for Research in Unani Medicine, Ministry of Healthand Family Welfare. Govt. of India; 2012.

17. Alam M, Mannan A, Siddique M, Ilahi A, Hijamah (cupping): A Graeco-Islamic Perspective. Journal of the International Society for the History of Islamic Medicine, 2012;10-11(19-20-2122):143-148.

18. Ahmad I, Nayab M, Ahmad T, Effect of gliding cupping with Roghan-e-Surkh in low back ache (Waja-uz-Zahr): a case series study. Drug Metabolism and Personalized Therarpy, 2021 Mar 26. doi: 10.1515/dmpt-2020-0177. Epub ahead of print. PMID: 33770821.

19. Lari A, Nayab M, Tausif M, Lari J, Alam A, Therapeutic potentials of hijama-bila-shart (Dry Cupping Therapy): A review. International Journal of Unani and Integrative Medicine, 2017; $1(1): 21-24$.

20. Nayab M, Anwar M, Qamri MA, Clinical study on Waja-ul-Mafasil and evaluation of efficacy of Hijamat-Bila-Shurt in the treatment. Indian Journal of Traditional Knowledge, 2011; 10(4):697-701.

21. Sheikh MH, Fasihuzzaman, Jabeen A, Siddiqui MA, Unani Concept and Management of Waja-Ul- Mafasil (Arthritis) with Special Reference to Hijamah (Cupping Therapy), Indo American Journal of Pharmaceutical Research, 2014; 4(2):1098-1103.

22. Qamri AM. Minhaj ul Ilaj (Urdu Translation of Ghina Muna), New Delhi: Central Council for Research in Unani Medicine, Ministry of Healthand Family Welfare. Govt. of India; 2008.

23. Anees S, Arafath Y, Naaz A, Khan MQ, Hijamah (Cupping therapy) as a Preventive Medicine - A Retro-Prospective Analytical Study. International Journal of AYUSH, 2015; 4(2):88-100.

24. Hasan I, Standardization of Cupping Therapy Points and Mechanism of Action in the Light of Science, Indo American Journal of Pharmaceutical Science, 2018; 5(1):249-261.

25. Rozenfeld E, Kalichman L, New is the well-forgotten old: The use of dry cupping in musculoskeletal medicine. Journal of Bodywork and Movement Therapies, 2016; 20(1):173-178. doi: 10.1016/jbmt.2015.11.009.

26. Farhadi K, Schwebel DC, Saeb M, Choubsaz M, Mohammadi R, Ahmadi A, The effectiveness of wetcupping for nonspecific low back pain in Iran: a randomized controlled trial. Complementary Therapies in Medicine, 2009; 17(1):9-15. doi: 10.1016/j.ctim.2008.05.003.

27. Nimrouzi M, Mahbodi A, Jaladat AM, Sadeghfard A, Zarshenas MM, Hijamat in traditional Persian medicine: risks and benefits. Journal of Evidence Based Complementary and Alternative Medicine, 2014; 19(2):128-136. doi $10.1177 / 2156587214524578$.

28. Al-Bedah A, Khalil M, Elolemy A, Hussein AA, AlQaed M, Al Mudaiheem $A$ et al., The use of wet cupping for persistent nonspecific low back pain: randomized controlled clinical trial Journal of Alternative and Complementary Medicine, 2015:1-5. doi: 10.1089/acm.2015.0065.

29. Kim JI, Kim TH, Lee MS, Kang JW, Kim KH, Choi JY et al., Evaluation of wet-cupping therapy for persistent non-specific low back pain: a randomised, waiting-list controlled, open-label, parallel-group pilot trial, Trials, 2011; 12(146):1-7. doi:10.1186/1745-6215-12- 146.

30. Mardani-Kivi M, Montazar R, Azizkhani M, Hashemi-Motlagh K, Wet-cupping is effective on persistent nonspecific low back pain: a randomized clinical trial, Chinese Journal of Integrative Medicine, 2019; 25(7):502-506. doi: 10.1007/s11655-0182996-0.

31. Lauche R, Cramer H, Choi KE, Rampp T, Saha FJ, Dobos GJ et al., The influence of a series of five dry cupping treatments on pain and mechanical thresholds in patients with chronic non-specific neck pain-a randomised controlled pilot study, BMC Complementary and Alternative Medicine, 2011; 11(63):1-1. doi:10.1186/1472-6882-11-63.

32. Cramer H, Lauche R, Hohmann C, Choi KE, Rampp T, Musial F et al., Randomized controlled trial of pulsating cupping (pneumatic pulsation therapy) for chronic neck pain. Forschende Komplementarmedizin, 2011; 18(6):327-34. doi: 10.1159/000335294.

33. Saha FJ, Schumann S, Cramer H, Hohmann C, Choi KE, Rolke R et al., The effects of cupping massage in patients with chronic neck pain- a randomized controlled trial. Complementary Medicine Research, 2017; 24(1):26-32. doi: 10.1159/000454872.

34. Arslan M, Gökgöz N, Dane Ş, The effect of traditional wet cupping on shoulder pain and neck pain: A pilot study. Complementary Therapies in Clinical Practice, 2016; 23:30-3. doi 10.1016/j.ctcp.2016.02.003.

35. Kim TH, Kang JW, Kim KH, Lee MH, Kim JE, Kim JH et al., Cupping 
for treating neck pain in video display terminal (VDT) users: a randomized controlled pilot trial. Journal of Occupational Health, 2012; 54(6):416-426.

36. Lauche R, Cramer H, Langhorst J, Dobos G, Cupping for chronic nonspecific neck pain: a 2-year follow-up, Complementary Medicine Research, 2013; 20(5):328-333. doi: 10.1159/000355634.

37. Wen MX, Ying W, Sheng-ai P, Wen-tao LV, Cheng-hui ZH, Mingyuan MU et al., Wet cupping therapy improves local blood perfusion and analgesic effects in patients with nerve-root type cervical spondylosis, Chinese Journal of Integrative Medicine, 2018; 24(11):830-834. doi: 10.1007/s11655-017-2925-7.

38. Khan AA, Jahangir U, Urooj S, Management of knee osteoarthritis with cupping therapy, Journal of Advanced Pharmaceutical Technology \& Research, 2013; 4(4):217-223. doi: 10.4103/2231-4040.121417.

39. Abdullah KS, Mohammed AS, Naveed M, Al-Eryani E, Ahmed AA, Al-Atany SM, Effect of Cupping (Al-Hijama) therapy in rheumatoid arthritis patients: A cohort study in Yemen, Dokkyo Journal of Medical Sciences, 2021; 48(02):189-199.

40. Bilal M, Khan RA, Therapeutic Effectiveness of Hijama in Sciatica Pain, Pharmacology and Pharmacy, 2016;7(8):326-330. doi: 10.4236/pp.2016.78040.

41. Shaikh N, Alam H, Effect of Hijama (Wet Cupping Therapy) In Sciatica Pain Management, International Journal of Advances in Health Sciences, 2020; 6(1):1-7.

42. Michalsen A, Bock S, Lüdtke R, Rampp T, Baecker M, Bachmann J et al., Effects of traditional cupping therapy in patients with carpal tunnel syndrome: a randomized controlled trial, Journal of Pain, 2009; 10(6):601-608. doi:10.1016/j.jpain.2008.12.013.

43. Mohammadi S, Roostayi MM, Naimi SS, Baghban AA, The effects of cupping therapy as a new approach in the physiotherapeutic management of carpal tunnel syndrome, Physiotherapy Research International, 2019; 24(3):1-7. doi: 10.1002/pri.1770.

44. Lari A, Nayab M, Efficacy of Hijamat-bila-Shart (Dry Cupping) in the Management of Waja-uz-Zahr (Low Back Pain): An Open Randomized Controlled Clinical Trial, International Journal of Herbal Medicine, 2018; 6(1):16-19.

45. Islam MU, Nayab M, Ansari AN, Effect of dry cupping versus soft and prolonged massage in the management of knee osteoarthritis - a randomized controlled clinical trial, Journal of Complementary Integrative Medicine, 2021 Mar 31. doi: 10.1515/jcim-2020-0350. Epub ahead of print. PMID: 33787191.

46. Sultana A, Rahman KU, Farzana AL, Efficacy of hijamat bila shurt (dry cupping) on intensity of pain in dysmenorrhoea-a preliminary study. Ancient Science of Life 2010; 30(2):47- 50.

47. Dadmehr M, Ayati MH, Rostami S, Akhtari E, Effectiveness of Dry Cupping Therapy in the Management of Uterine Fibroid: A Case Report, Traditional and Integrative Medicine, 2020; 5(2):86-92.

48. Sultana A, Rahman KU, Effect of traditional dry cupping therapy on heavy menstrual bleeding in menorrhagia: A preliminary study, Tang Humanitus Medicine, 2012; 2(4):33-1. doi:10.5667/tang.2012.0030.

49. Abdul jabbar H, Gazzaz A, Mourad S, Oraif A, Hijama (wet cupping) for female infertility treatment: a pilot study, International Journal of Reproduction, Contraception, Obstetrics and Gynecology, 2016; 5(11):3799-3801. doi: $10.5667 /$ tang.2012.0030.

50. Aziz khani M, Dastjerdi MV, Arani MT, Pirjani R, Sepidarkish M, Ghorat $\mathrm{F}$ et al., Traditional dry cupping therapy versus medroxyprogesterone acetate in the treatment of idiopathic menorrhagia: a randomized controlled trial, Iran Red Crescent Medical Journal 2018; 20(2). doi: 10.5812/ircmj.60508.

51. Khan AA, Treatment of polycystic ovarian syndrome by wet cupping-a case report. Journal of Ayurveda and Holistic Medicine, 2015; 3(3):41-45.

52. Mokaberinejad R, Rampisheh Z, Aliasl J, Akhtari E, The comparison of fennel infusion plus dry cupping versus metformin in management of oligomenorrhoea in patients with polycysticovary syndrome: a randomised clinical trial, Journal of Obstetrics and Gynecology, 2019; 39(5):652-8. doi: 10.1080/01443615.2018.1541232.

53. Ersoy S, Benli AR, Continue or stop applying wet cupping therapy (al-hijamah) in migraine headache: A randomized controlled trial, Complementary Therapies in Clinical Practice, 2020; 38:1-6. doi: 10.1016/j.ctcp.2019.101065.

54. Seo J, Chu H, Kim CH, Sung KK, Lee S, Cupping Therapy for Migraine: A PRISMA- Compliant Systematic Review and MetaAnalysis of Randomized Controlled Trials, Evidence-Based Complementary and Alternative Medicine, 2021; 2021:1-9. doi: $10.1155 / 2021 / 7582581$.

55. Ali M, Ansari AN, Nayab M, Anjum H, Ansari S, Efficacy of a PolyHerbal Unani Formulation and Dry Cupping in treatment of PostStroke Hemiplegia: An Exploratory, Single Arm Clinical Trial, Journal of Advances in Integrative Medicine, 2020. DOI: https://doi.org/10.1016/j.aimed.2020.11.001

56. Aleyeidi NA, Aseri KS, Matbouli SM, Sulaiamani AA, Kobeisy SA, Effects of wet-cupping on blood pressure in hypertensive patients: a randomized controlled trial, Journal of Integrative Medicine, 2015; 13(6):391-399. doi: 10.1016/S20954964(15)60197-2.

57. Husain NR, Hairon SM, Zain RM, Bakar M, Bee TG, Ismail MS, The effects of wet cupping therapy on fasting blood sugar, renal function parameters, and endothelial function: a single- arm intervention study, Oman Medical Journal, 2020; 35(2):e108. doi:10.500/omj.2020.26.

58. Niasari M, Kosari F, Ahmadi A, The effect of wet cupping on serum lipid concentrations of clinically healthy young men: a randomized controlled trial, Journal of Altern and Complementary Medicine, 2007; 13(1):79-82. doi: 10.1089/acm.2006.4226.

59. Fadli, Ahmad AS, Safruddin, Baharuddin R, Februanti S, Effect of Wet Cupping Against Increased Arterial Baroreflex Sensitivity in Hypertensive Patients: Randomized Controlled Trial (RCT), Journal of Critical Reviews, 2020; 7(14):671-676. doi: 10.31838/jcr.07.14.118. 